\title{
Tinjauan Estetika Hiasan Kaca Patri Pada Gereja Katolik Inkulturatif Paroki Santo Fransiskus Asisi Berastagi Berdasarkan Prinsip Seni Rupa
}

\author{
Aesthetic Overview of Stained Glass Decoration at the \\ Inculturative Catholic Church of the Parish of Saint Fransiskus \\ Asisi Berastagi Based on the Principles of Fine Arts
}

\author{
Samuel Joan Parasian Siregar* \\ Program Studi Pendidikan Seni Rupa, Jurusan Seni Rupa, Fakultas Bahasa Dan Seni \\ Universitas Negeri Medan
}

Diterima: 11 Mei 2021 Direview: 11 Mei 2021; Disetujui: 06 Agustus 2021

*Coresponding Email: samuelioanparasian@gmail.com

\begin{abstract}
Abstrak
Penelitian ini bertujuan untuk mendeskripsikan kualitas estetis karya hiasan kaca patri pada gereja Katolik Santo Fransiskus Asisi Berastagi berdasarkan dari prinsip-prinsip seni rupa khususnya dalam aspek kesatuan, keseimbangan, irama, proporsi, komposisi, dan center of interest (pusat perhatian). Penelitian ini menggunakan metode deskriptif kualitatif. Subjek dalam penelitian ini adalah sebagian kaca patri pada gereja Katolik Santo Fransiskus Asisi yang juga merupakan sampel dalam penelitian iniberjumlah lima sampel. Teknik pengambilan sampel yang digunakan ialah total sampling. Hasil penelitian ini menjelaskan bahwa kualitas visual karya kaca patri pada gereja Katolik Santo Fransiskus tersebut, jika ditinjau berdasarkan prinsip-prinsip seni, menunjukkan beberapa kekurangan pada karyakarya tersebut dapat dilihat dari banyaknya karya yang hanya memperoleh poin dibawah tiga $(<3)$, salah satunya ialah masih terdapat sebagian besar karya yang memiliki kekurangan dari segi komposisi yang tidak terdapat keseimbangan didalamnya, hal ini dikarenakan pemilihan warna serta penempatan objekobjek yang kurang tepat, ditambah masih terdapat beberapa kekurangan objek yang terbentuk kurang proporsional. Namun walaupun demikian, masih terdapat juga beberapa karya yang memiliki kualitas cukup hingga sangat baik, dimana karya-karya tersebut mampu memperoleh poin diatas tiga $(>3)$.
\end{abstract}

Kata kunci: Tinjauan; Kaca Patri; Estetika; Prinsip-prinsip Seni Rupa

\section{Abstract}

This study aims to describe the aesthetic quality of the stained glass decoration work at the Catholic Church of St. Francis of Asisi Berastagi based on the principles of fine arts, especially in the aspects of unity, balance, rhythm, proportion, composition, and center of interest. This study used descriptive qualitative method. The subjects in this study were part of the stained glass in the Catholic Church of St. Francis of Asisi, which is also a sample in this study, amounting to five samples. The sampling technique used was total sampling. The results of this study explain that the visual quality of the stained glass works in the Catholic Church of St. Francis, if viewed based on the principles of art, shows some deficiencies in these works can be seen from the number of works that only get points below three (<3), wrong the only thing is that there are still most of the works that have shortcomings in terms of composition and there is no balance in them, this is due to the color selection and placement of objects that are not quite right, plus there are still some deficiencies in the objects that are formed that are not proportional. However, even so, there are still some works that have sufficient to excellent quality, where these works are able to get points above three (>3).

Keywords: Overview; Stained Glass; Aesthetics; Principles of Fine Art

How to Cite: Siregar, S.J.P., (2021). Tinjauan Estetis Hiasan Kaca Patri Pada Gereja Katolik Inkulturatif Paroki Santo Fransiskus Asisi, Berastagi Berdasarkan Prinsip Seni Rupa. Journal of Education, Humaniora and Social Sciences (JEHSS). 4 (2): 660-670. 


\section{PENDAHULUAN}

Kaca patri ialah suatu seni kaca yang mulai berkembang pada masa arsitektur gotik. Namun untuk teknik pembuatan dan hal-hal yang menyangkut tentang seni kaca ini masih jarang terdengar di nusantara, dan dalam perkembangan zaman yang semakin maju bahkan teknik hingga bahan-bahan yang digunakan juga sudah semakin beragam.

Ciri khas bangunan yang diterapkan pada gereja ini adalah bangunan bermotif dan bernuansa rumah adat Karo. Kaca patri pada bangunan tersebut diadaptasi dari gambar-gambar nuansa khas umat kristiani. Bentuk-bentuk kaca patri pun digambarkan tidak hanya memunculkan nuansa estetis saja, melainkan memiliki makna yang tersirat di dalamnya. Pembentukan objek yang dicapai juga memuaskan, dimana penikmat dapat dengan mudah mengamati tiap-tiap objek dalam hiasan kaca patri tersebut. Tidak diragukan lagi bahwa pada proses pembuatannya, bahan yang digunakan merupakan bahan dengan kualitas yang baik dan penyelesaian hiasan kaca patri ini juga dilakukan dengan teknik yang baik sehingga secara umum menampilkan hasil yang baik pula, namun belum dikatehui secara pasti jika dinilai dengan menggunakan teori prinsip seni rupa. (Utami dkk, 2020).

Nilai estetik pada seni hiasan kaca patri ini juga sangat berpengaruh terhadap elemen elemen visual yang terdapat didalamnya. Hal ini merupakan salah satu poin terbesar karena penempatan elemen elemen visuallah yang menjadi pemicu akan kemampuan penikmat mengetahui ide ataupun cerita apa yang ingin disajikan oleh si pengrajin. Pada hiasan kaca patri yang terdapat di gereja Katolik ini terdapat elemen elemen visual yang secara umum sudah mampu menyampaikan ide ide cerita didalamnya, dimana cerita yang diambil tentu saja berlandaskan tentang cerita alkitabiah.

Berdasarkan hasil wawancara peneliti bersama Pastor Leo Joosten, OFMCap. selaku koordinator pembangunan gereja, peletakan hiasan kaca patri pada bangunan gereja memiliki beberapa alasan. Tujuan pertama ialah dimana sudah merupakan suatu ciri khas gereja Katolik dengan bentuk arsitektur yang di sandingkan dengan hiasan kaca patri. Kedua, suatu bentuk penuangan cerita Alkitabiah sebagai pedoman keimanan bagi seluruh jemaat. Pastor kembali menuturkan bahwa bentuk-bentuk pada seluruh hiasan kaca patri tersebut menggambarkan kisah tentang Tuhan Allah dalam penciptaan bumi dan segala isinya, ketujuh sakramen dalam agama Katolik serta beberapa kejadian-kejadian besar dalam Alkitab. Namun, hal yang menjadi sorotan utama ialah dimana pastor kembali menuturkan bahwa pengrajin kaca patri tersebut bukan berasal dari lingkungan tersebut, ditambah lagi hanya beberapa literatur yang ditemukan tentang sejarah kaca patri di Indonesia, dan ada beberapa literatur yang juga merupakan hasil terjemahan dari bahasa asing. Hal ini dapat disimpulkan bahwa masih minimnya pengetahuan tentang teknik pembuatan kaca patri.

Pembahasan terkait pernah dilakukan oleh Prema (2015) dengan judul pembahasan "Analisis Bentuk Relief Di Kuil Shri Mariamman Medan Ditinjau Dari Prinsip-Prinsip Seni Rupa". Tujuan penelitian ini adalah untuk mendeskripsikan dan mengkaji bentuk relief di kuil berdasarkan prinsip-prinsip seni rupa dan mendeskripsikan serta mengkaji bentuk relief di kuil Shri Mariamman ditinjau dari elemen visualnya. Hasil penelitian ini menunjukkan relief-relief pada kuil tersebut sudah memenuhi prinsip-prinsip seni rupa secara visualnya. Sehingga penelitian ini dapat dijadikan pedoman dalam proses meninjau karya kaca patri di gereja Katolik Inkulturatif Santo Fransiskus Asisi Berastagi berdasarkan prinsip-prinsip seni rupa. (Utoyo dkk, 2020)

Selanjutnya Nainggolan (2018) dengan judul “Analisis Karya Gambar Bentuk Siswa Kelas VII SMP Negeri 1 Simangumban Berdasarkan Prinsip-Prinsip Seni Rupa". Berdasarkan hasil penelitian ini dapat disimpulkan bahwa karya-karya siswa disekolah tersebut mendapatkan hasil dengan nilai yang cukup dengan rata-rata 62,13. Sehingga penelitian ini dapat dijadikan pedoman dalam proses penentuan nilai dari hasil tinjauan karya kaca patri dengan berdasarkan prinsip-prinsip seni.(Sinaga \& Triyanto, 2020).

Kemudian Hutama (2005) pernah melakukan penelitian yang bertujuan untuk mendeskripsikan penggunaan motif ragam hias pada hiasan-hiasan kaca patri di Jakarta serta 
Samuel Joan Parasian Siregar, Tinjauan Estetis Hiasan Kaca Patri Pada Gereja Katolik Inkulturatif Paroki Santo

Fransiskus Asisi, Berastagi Berdasarkan Prinsip Seni Rupa

untuk mengetengahkan seni ragam hias pada stained glass pada jendela-jendela bangunan di Jakarta dan diperoleh hasil berupa sumber ide dalam pembuatan hiasaan-hiasaan kaca serta dapat diharapkan dapat menjadi pedoman dalam membuat sebuah karya pada media kaca. Sehingga penelitian ini dapat dijadikan pedoman dalam mendalami seni kaca patri tersebut baik dari segi sejarah maupun penerapannya.

Adapun tujuan dari penelitian ini yaitu mendeskripsikan kualitas visual dalam penyampaian ide didalam hiasan kaca patri yang ada pada bangunan gereja Katolik Inkulturatif paroki Santo Fransiskus Asisi di Berastagi. Jadi bagi jemaat Katolik agar lebih mengerti histori dari sebuah hiasan kaca di gereja, dapat lebih dipahami segi kualitas estetiknya dan agar tidak hanya memandang kaca tersebut sebagai hiasan semata. Serta agar dapat menilai suatu karya (termasuk hiasan kaca patri) berdasarkan prinsip seni rupa.

\section{METODE PENELITIAN}

Menurut Sugiyono (2010) metode penelitian adalah cara ilmiah untuk mendapatkan data dengan tujuan dan kegunaaan tertentu.Metode yang digunakan dalam penelitian ini adalah deskriptif kualitatif.Metode deskriptif dapat disimpulkan sebagai sebuah metode yang bertujuan untuk melukiskan atau menggambarkan keadaan di lapangan secara sistematis dengan fakta-fakta yang tepat serta data yang saling berhubungan, dimana bukan hanya mencari kebenaran yang mutlak tetapi pada hakekatnya mencari pemahaman observasi.

Menurut Sugiyono (2010) populasi adalah jumlah seluruh individu yang menjadi target penelitian. Populasi berarti keseluruhan subjek penelitian, dengan kata lain peneliti wajib meneliti semua elemen yang ada dalam wilayah penelitian.Berdasarkan observasi yang telah dilakukan, populasi yang akan menjadi objek yang diteliti ialah lima kaca.Sampel adalah sebagian atau wakil populasi yang diteliti (Arikunto, 2006). Dinamakan penelitian sampel apabila kita bermaksud untuk menggeneralisasikan hasil penelitian sampel. Maka sampel yang digunakan dalam penelitian ini adalah total sampling, yaitu teknik pengambilan sampel dengan petimbangan tertentu. Sampel pada penelitian ini adalah lima kaca patri yang ada di bangunan Gereja Katolik Inkulturatif Karo Berastagi.

Dalam suatu penelitian selalu terjadi proses pengumpulan data. Proses tersebut dilakukan dengan metode tertentu, dan jenis metode dapat dipilih dan digunakan tergantung pada sifat dan karakteristik penelitian yang digunakan. Beberapa cara peneliti dalam mengumpulkan data adalah sebagai berikut:Observasi; Studi Kepustakaan; Wawancara (Interview); Dokumentasi.

Wawancara adalah proses tanya jawab dalam penelitian yang berlangsung secara lisan antara dua orang atau lebih, bertatap muka, mendengarkan secara langsung informasi-informasi atau keterangan-keterangan (Narbuko, 2005). Dalam hal ini, peneliti akan mewawancarai beberapa pihak terkait diantaranya: Pastor Leo Joosten, OFMCap selaku Koordinator Utama pembangunan Gereja Inkulturatif Karo.Adapun langkah-langkah penelitiannya adalah sebagai berikut:Menyusun kegiatan jadwal penelitian; Observasi kaca patri pada gereja Katolik Inkulturatif Karo di Berastagi; Mendokumentasikan kaca patri pada gereja tersebut;Menganalisis teknik pembuatan kaca patri pada gereja tersebut; Menganalisis bahan yang terkandung pada hiasan kaca patri gereja tersebut; Dari data yang terkumpul kemudian ditarik kesimpulan secara umum sebagai temuan dalam penelitian.

Untuk menghitung rata-rata hasil penilaian, data kuantitatif dikonversikan menjadi data kualitatif, yaitu; 5 = sangat baik, 4 = baik, 3 = cukup, 2 = tidak baik, 1 = sangat tidak baik. Hasil penilaian rata-rata dari deskripsi karya kaca patri tersebut untuk mengukur sejauh mana persamaan dan perbedaan nilai daripada karya kaca patri tersebut. Kemudian sampul majalah yang telah dideskripsikan secara kualitatif oleh peneliti akan dianalisis atau dikaji, penilaian dilakukan dalam bentuk tabulasi berupa instrumen penilaian untuk mempermudah dan memperjelas hasil analisis dari penelitian yang sesuai dengan tujuan penelitian untuk membuat suatu kesimpulan tentang bagaimana prinsip kesatuan, keseimbangan, irama, proporsi, komposisi, center of interest pada karya kaca patri tersebut. Hasilnya akan dilakukan penarikan kesimpulan dari pengolahan data analisis deskriptif dan tabulasi berupa instrumen penelitian. 
Indikator yang digunakan dalaminstrumen penilaian yang akan digunakan adalah sebagai berikut:

Tabel 1. Indikator Penilaian

\begin{tabular}{ccc}
\hline Keterangan & Skor & Indikator \\
\hline Sangat Baik & 5 & $\begin{array}{c}\text { Kesatuan } \\
\text { Keseimbangan } \\
\text { Irama } \\
\text { Proporsi } \\
\text { Komposisi } \\
\text { Center of Interest }\end{array}$ \\
\hline Baik & 4 & Jika salah satu dari poin keterangan diatas tidak \\
terdapat pada karya kaca patri.
\end{tabular}

\section{HASIL DAN PEMBAHASAN \\ Seni Kaca Patri}

Kaca patri berasal dari bahasa Inggris, yaitu Stained Glass. Seni diatas kaca ini telah berubah dari waktu ke waktu. Dari peradaban Yunani-Romawi sampai dengan Amerika. Periode awal produksi kaca patri sekitar tahun 1000-1500 Masehi, pada zaman Gothic, karena itu jendela kaca patri yang diciptakan hampir mayoritas berada dalam gaya Gothic. Pengrajin pada abad pertengahan selama zaman Gothic lebih tertarik untuk mengilustrasikan ide dari menciptakan gambar-gambar realistis (Hudson, 2008).

Seni kaca patri berkembang di Eropa pada masa abad pertengahan. Dalam sejarah seni rupa Barat, kaca patri banyak ditemukan pada bagian bangunan dengan gaya arsitektur Gothic. Sebagaimana dikatakan Fichner (1992): The assembling of pieces of colored or stained glass reached a height at about the same time that architects and builders used stained glass windows to bring light into their gothic cathedrals and to represent religious figures and scenes.

Perakitan kaca patri mencapai ketinggian yang hampir sama dengan bangunan dimana arsitek dan pembangun menggunakan jendela kaca patri untuk membawa cahaya kedalam katedral dan untuk menggambarkan tokoh-tokoh religius serta adegan-adegan keagamaan.Kaca patri biasanya identik dengan bangunan gereja Katolik. Penempatan kaca patri ditempatkan pada bagian belakang mimbar gereja. Adapun gambar yang terdapat dalam kaca patri ialah figur malaikat, simbol dari penginjil-penginjil yang menulis kitab perjanjian baru sebagai objek utama yang kemudian di hiasi objek dedaunan, hewan-hewan kecil atau burung-burung dan lukisan huruf yang di bentuk menyerupai bingkai. Salah satu contoh kaca patri yang terkenal pada abad ke-13 terdapat di katedral Chartres, dimana kaca patri ini menceritakan tentang garis keturunan Yesus Kristus.Selain itu kaca patri terdapat juga hampir disetiap bangunan gereja katolik yang tersebar diseluruh dunia.

Dalam pembuatannya, hiasan kaca patri memiliki dua proses yang dilakukan secara terpisah setelah desain selesai dirancang. Pertama-tama pengrajin kaca patri haruslah terlebih dahulu membuat kaca sesuai dengan warna yang dibutuhkan, dalam pembuatan kaca tersebut terdapat beberapa campuran untuk menghasilkan warna-warna yang berbeda seperti campuran garam pada cairan kaca akan menghasilkan warna kuning, kobalt untuk menghasilkan warna biru, emasmembuat warna cranberry atau merah, perak untuk warna emas serta tembaga untuk menghasilkan warna hijau (Warrington,1998).Membuat kaca dengan warna yang dibutuhkan merupakan langkah awal dalam pembuatan kaca patri dan setelah itulah baru kaca dipotong lalu dipasangkan pada panel yang sudah dirancang sesuai desain. Dalam pembuatan panel memiliki 
empat jenis teknik yang dimana dapat dikelompokkan berdasarkan bahan yang digunakan, diantaranya ialah pembuatan panel dengan bahan kuningan yang dilelehkan, bahan kuningan merupakan bahan yang pertama kali digunakan dalam pembuatan kaca patri pada masa gotik,namun seiring perkembangan waktu, bahan lain yang lebih kompleks pun mulai ditemukan, yang pertama ialah menggunakan logam yang di solder, kemudian berkembang lagi dengan nama yang sering disebut "Tiffany style", teknik ini menggunakan pita foil tembaga untuk membungkus pinggiran masing-masing kaca dan dihubungkan satu sama lain dengan timah yang di solder, dan teknik yang terakhir ialah menggunakan lem epoxy untuk merekatkan tiap-tiap kaca, teknik inilah yang berkembang pada masa modern sekarang.

Gagasan awal dari nilai dan kegunaan teknik patri yang digabung dengan teknik mewarnai kaca ialah untuk menghiasi jendela pada mimbar sebuah gereja. Seni kaca patri sudah dikenal sejak abad ketiga Masehi, tepatnya di Roma yang menggunakan seni kaca patri sebagai penghias interior pada gedung-gedung gereja.

Di Indonesia kerajinan kaca dikenal pertama kali pada saat pemerintahan kolonial Belanda. Pada saat itu kaca teramasuk jenis barang mewah dan sangat mahal, ini terbukti dari arsip laporan tahunan VOC di Batavia. Disana terdapat beberapa catatan tentan impor barang-barang kerajinan kaca dari Belanda atau Eropa. Barang-barang kerajinan kaca itu untuk dijual dan diberikan sebagai hadiah kepada raja-raja atau sultan-sultan di Indonesia (Moelya, 2014).

Kaca patri telah mengalami perkembangan yang sangat signifikan dari pertama kali muncul sampai sekarang. Perkembangan kaca patri tidak terbatas pada ornamen dan gaya yang digunakan saja, tetapi juga mencakup kegunaan kaca patri sendiri pada gereja-gereja di Indonesia. Salah satu alasan kaca patri dapat berkembang di Indonesia adalah karena Indonesia merupakan negara tropis, dengan memanfaatkan sinar matahari sehingga cahayanya yang masuk menembus panel-panel kaca patri memberikan efek yang indah (Putri, 2012).

\section{Deskripsi Karya}

Penciptaan. Penciptaan adalah permulaan dari segala sesuatu di muka bumi. Hal ini tertulis jelas dalam kitab kejadian, dalam kaca patri ini digambarkan objek-objek yang menggambarkan bagaimana penciptaan itu terjadi. Terdapat objek gambar bulan, matahari, bintang-bintang, pepohonan hingga alam dan binatang-binatang yang diwakilkan dengan objek hewan berbentuk rusa.

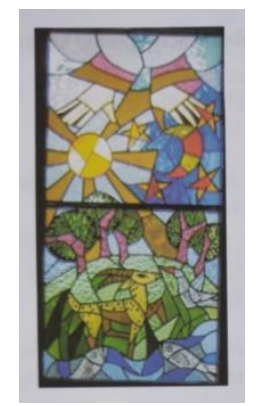

Gambar 1. Penciptaan

Sumber: Samuel Joan Parasian Siregar

Adam dan Hawa. Adam dan Hawa berasal juga dari tangan Tuhan dan diantar oleh tangan Tuhan. Dan Allah berkata:"berkembang biaklah". Dalam kitab kejadian juga dikatakan Tuhan awalnya hanya menciptakan laki-laki, dan selanjutnya menciptakan wanita dari tulang rusuk si lelaki (adam). Dalam kaca patri ini digambarkan objek seorang perempuan dan laki-laki yang mewakili tokoh Adam dan Hawa. 


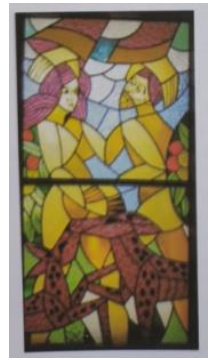

Gambar 2. Adam dan Hawa

Sumber:Samuel Joan Parasian Siregar

Sakramen Perkawinan. Dalam hiasan kaca patri ini digambarkan tangan Tuhan yang berada di atas pasangan pengantin Karo, yang dimana disesuaikan dengan konsep gereja yang mengambil konsep inkulturasi, dimana ajaran agama dipersatukan dengan konsep kebudayaan. Di sebelah bawah juga terlihat dikembangkan "uis" (ulos) yang mempersatukan mereka.

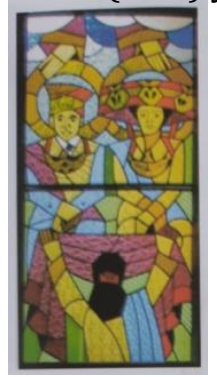

Gambar 3. Sakramen Perkawinan Sumber:Samuel Joan Parasian Siregar

Keluarga Kudus di Nazareth. Kaca patri ini menceritakan tentang kelahiran Yesus di Nazareth, yang mana diceritakan bahwa Yesus lahir di kandang domba dalam kesederhanaan dan kekudusan Nya. Dalam alkitab diceritakan bahwa di Nazareth tidak ada penginapan ataupun tempat singgah yang dapat di singgahi oleh Yusuf dan Maria, sementara Maria merasa sebentar lagi akan segera melahirkan, hingga akhirnya mereka pun beristirahat di sebuah kandang domba, yang dimana akhirnya proses persalinan pun terpaksa dilakukan disana. Digambarkan objek hewan ternak dan domba yang berada di posisi depan sebagai bentuk penggambaran situasi kandang domba tersebut, dan terdapat objek seorang wanita yang mewakilkan tokoh Maria dan bayi yang digendongnya mewakili tokoh Yesus, serta seorang lelaki yang berdiri dengan posisi seperti menyambut si bayi yang mewakili tokoh Yusuf.

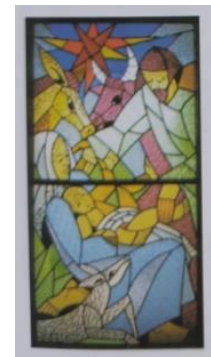

Gambar 4.Keluarga Kudus di Nazareth Sumber:Samuel Joan Parasian Siregar

Bahtera Nuh. Kisah Bahtera Nuh menurut Kitab Kejadian pasal 6-9, dimulai ketika Allah mengamati perilaku jahat manusia dan memutuskan untuk mengirimkan banjir besar ke seluruh permukaan bumi. Namun Allah tetap melihat Nuh yang tetap setia, Dia pun memerintahkan Nuh 
agar membangun sebuah kapal raksasa untuk menyelamatkan keluarganya dan hewan" dimuka bumi masing-masing sepasang. Banjir pun dating dan menenggelamkan seluruh permukaan bumi, hanya Nuh dan seluruh yang berada di kapalnya lah yang selamat. Kejadian tersebut digambarkan dalam kaca patri ini, dapat dilihat objek-objek yang mewakili cerita, diantaranya gambar objek menyerupai kapal dan seorang lelaki diatasnya, serta air di bagian bawah, dan burung merpati yang membawa dahan olive sebagai pertanda air telah surut.

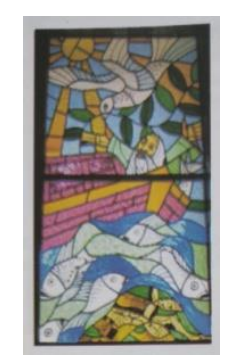

Gambar 5. Bahtera Nuh

Sumber:Samuel Joan Parasian Siregar

\section{Prinsip-Prinsip Seni menjadi Dasar Penentuan Kualitas Estetis}

Dalam pembahasan hasil penelitian ini, peneliti mendeskripsikan tinjauan estetis dengan menjadikan prinsip-prinsip seni menjadi dasar penentuan kualitas estetis karya-karya kaca patri tersebut.

Tabel 2. Pembahasan Karya

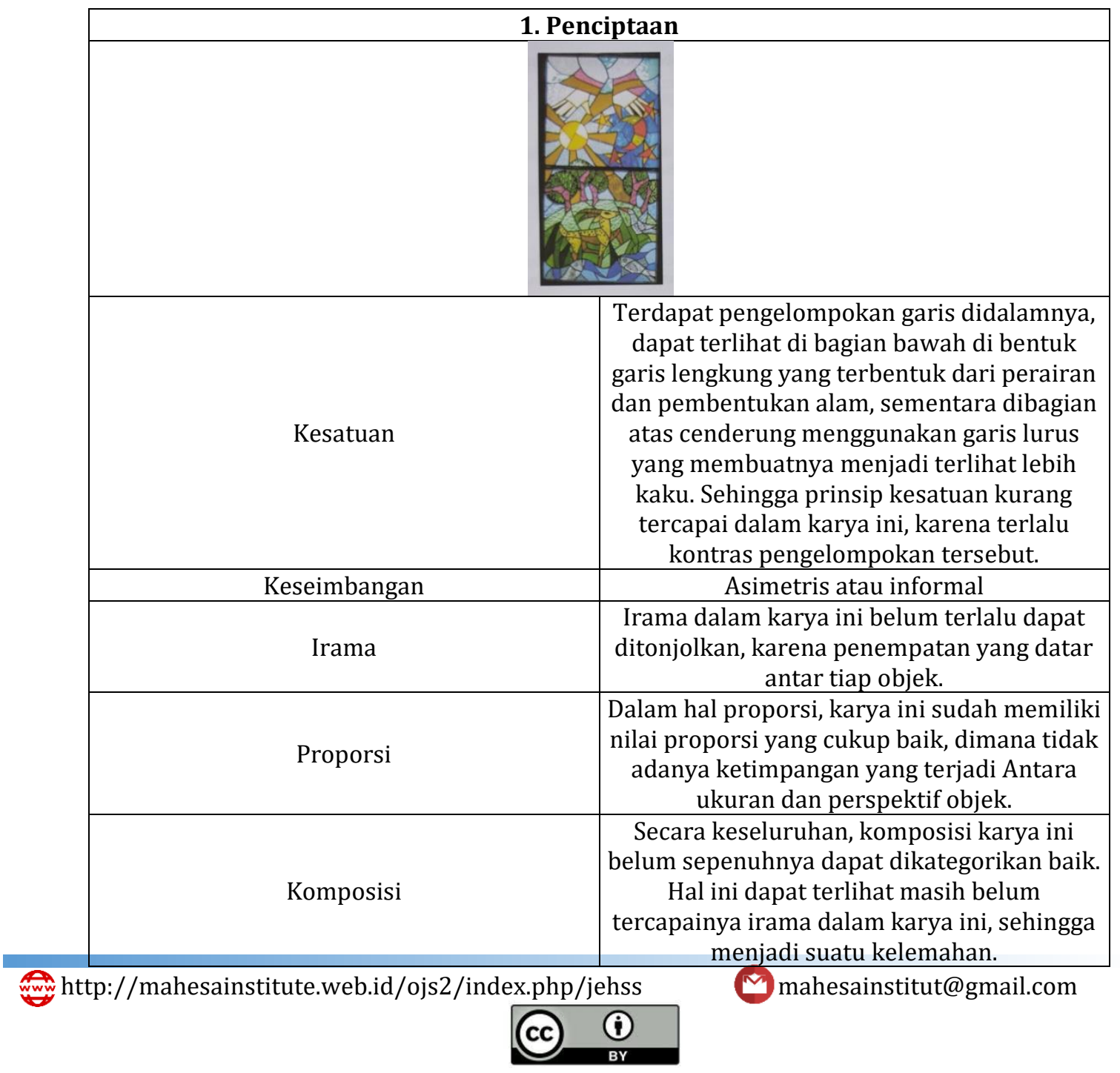


Vol 4, No. 2, November 2021: 660-670

\begin{tabular}{|c|c|}
\hline Center of Interest & $\begin{array}{c}\text { Untuk pusat dalam karya ini terlihat pada } \\
\text { bentuk tangan di bagian atas, hal ini dapat } \\
\text { disimpulkan karena perbedaan kepadatan } \\
\text { garis yang lebih renggang sehingga } \\
\text { menjadikannya bagian dengan kontras } \\
\text { terkuat. }\end{array}$ \\
\hline \multicolumn{2}{|c|}{ 2. Adam dan Hawa } \\
\hline \multicolumn{2}{|c|}{$\frac{21}{212}$} \\
\hline Kesatuan & $\begin{array}{c}\text { Jenis wana yang digunakan dominan coklat } \\
\text { sehingga menimbulkan kesan monochrome } \\
\text { didalamnya. Hal ini menjadikan kesatuan } \\
\text { yang kuat di dalam karya ini. }\end{array}$ \\
\hline Keseimbangan & Asimetri atau informal \\
\hline Irama & $\begin{array}{l}\text { Belum terlihat pembentukan irama dalam } \\
\text { karya ini. }\end{array}$ \\
\hline Proporsi & $\begin{array}{c}\text { Dalam karya ini, proporsi yang digambarkan } \\
\text { sudah baik. Dapat dilihat perbandingan } \\
\text { ukuran proporsi tubuh manusia dan hewan } \\
\text { yang sesuai. }\end{array}$ \\
\hline Komposisi & $\begin{array}{l}\text { Komposisi dalam karya ini sudah baik, tidak } \\
\text { terlihat adanya objek ataupun warna yang } \\
\text { mengganggu atau secara keseluruhan sudah } \\
\text { seimbang satu sama lain. }\end{array}$ \\
\hline Center of Interest & $\begin{array}{c}\text { Objek kedua manusia menjadi pusat utama } \\
\text { dalam karya ini. }\end{array}$ \\
\hline \multicolumn{2}{|c|}{ 3. Sakramen Perkawinan } \\
\hline \multicolumn{2}{|c|}{ 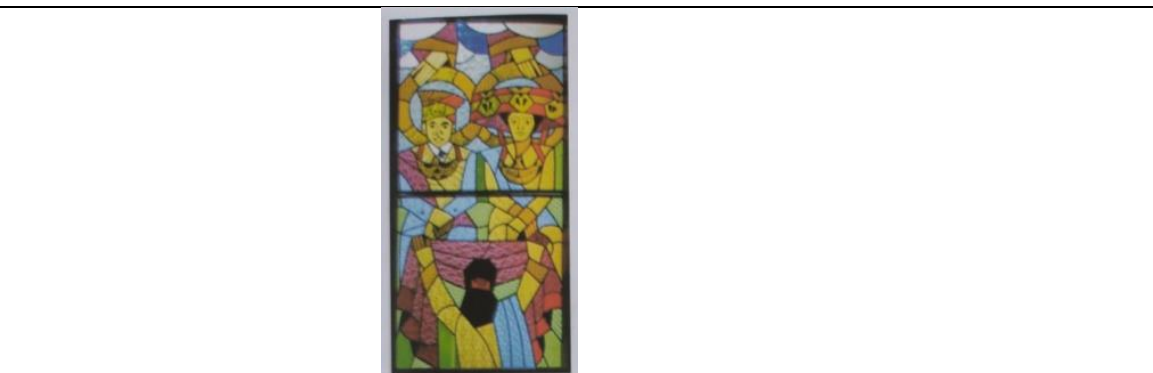 } \\
\hline Kesatuan & $\begin{array}{l}\text { Terdapat pola simetris yang membentuk } \\
\text { gambar pada objek, dimulai dari bentuk } \\
\text { tangan pada bagian atas hingga gambar } \\
\text { manusia yang memegang sebuah kain di } \\
\text { bagian bawah. Hal ini menjadi satu bentuk } \\
\text { kesatuan dalam karya ini. }\end{array}$ \\
\hline Keseimbangan & Simetris \\
\hline Irama & $\begin{array}{l}\text { Terdapat irama dari penempatan objek } \\
\text { paling depan hinggak ke belakang. }\end{array}$ \\
\hline Proporsi & $\begin{array}{c}\text { Perbandingan proporsi antar objek sudah } \\
\text { baik. Proporsi tubuh manusia dalam gambar } \\
\text { ini juga sudah sesuai. }\end{array}$ \\
\hline Komposisi & $\begin{array}{l}\text { Secara keseluruhan komposisi dalam karya } \\
\text { ini sudah memiliki keseimbangan. Mulai dari }\end{array}$ \\
\hline
\end{tabular}


Samuel Joan Parasian Siregar, Tinjauan Estetis Hiasan Kaca Patri Pada Gereja Katolik Inkulturatif Paroki Santo Fransiskus Asisi, Berastagi Berdasarkan Prinsip Seni Rupa

\begin{tabular}{|c|c|}
\hline & $\begin{array}{c}\text { warna yang hingga objek-objek yang } \\
\text { yerdapat didalamnya. }\end{array}$ \\
\hline Center of Interest & $\begin{array}{c}\text { Dalam menentukan pusat utama dalam } \\
\text { karya ini dapat dilihat langsung karena pola } \\
\text { yang dibentuk, yang dimana pola tersebutlah } \\
\text { membentuk kedua objek manusia di bagian } \\
\text { tengah menjadi pusat utamanya. }\end{array}$ \\
\hline \multicolumn{2}{|c|}{ 4. Keluarga Kudus di Nazareth } \\
\hline \multicolumn{2}{|c|}{\begin{tabular}{c|c} 
Pembentukan objek-objek dalam karya \\
tersebut saling berhubungan sehingga \\
mampu menciptakan suasana yang sesuai \\
dengan pesan dalam karya ini. Hanya saja \\
objek kemerahan pada bagian atas memiliki \\
warna yang terlalu kontras disbanding \\
dengan objek lainnya, yang menjadikan \\
sebuah kejanggalan.
\end{tabular}} \\
\hline Keseimbangan & Asimetri atau informal \\
\hline Irama & $\begin{array}{c}\text { Secara keseluruhan irama yang dibangun } \\
\text { sudah baik, dimana penempatan objek yang } \\
\text { mengarah ke objek utamanya. }\end{array}$ \\
\hline Proporsi & $\begin{array}{c}\text { Untuk proporsi manusia dan hewan } \\
\text { disekitarnya sudah memiliki ukuran yang } \\
\text { seimbang antar objeknya. }\end{array}$ \\
\hline Komposisi & $\begin{array}{l}\text { Karya ini memiliki sebuah kejanggalan yang } \\
\text { dimana mengurangi tingkat keseimbangan } \\
\text { didalamnya. Dimana objek kemerahan } \\
\text { dibagian atas terlalu mendominasi sehingga } \\
\text { mengurangi focus pada objek utamanya. }\end{array}$ \\
\hline Center of Interest & $\begin{array}{c}\text { Objek-objek dalam karya ini mengarahkan } \\
\text { pandangan pada objek utama yaitu seorang } \\
\text { bayi yang dapat disimpulkan menjadi objek } \\
\text { utamanya. }\end{array}$ \\
\hline \multicolumn{2}{|c|}{ 5. Bahtera Nuh } \\
\hline \multicolumn{2}{|c|}{ inger } \\
\hline Kesatuan & $\begin{array}{c}\text { Repetisi garis pembentuk objek kapal } \\
\text { menjadi sebuah kesatuan dalam karya ini. }\end{array}$ \\
\hline Keseimbangan & Asimetri atau informal \\
\hline Irama & $\begin{array}{c}\text { Terlalu beragamnya warna dan pola garis } \\
\text { justru menjadi kelemahan karya ini dalam } \\
\text { menciptakan irama didalamnya. }\end{array}$ \\
\hline
\end{tabular}


Vol 4, No. 2, November 2021: 660-670

\begin{tabular}{|c|c|}
\hline Proporsi & $\begin{array}{c}\text { Dalam karya ini terdapat kekurangan yang } \\
\text { sangat terlihat dalam hal proporsi, dimana } \\
\text { perbandingan ukuran antara manusia dan } \\
\text { hewan seperti burung dan ikan yang tidak } \\
\text { sesuai. }\end{array}$ \\
\hline Komposisi & $\begin{array}{c}\text { Komposisi dalam karya ini belum dapat } \\
\text { dikatakan baik, karena perbandingan ukuran } \\
\text { yang tidak sesuai antar objek didalamnya. }\end{array}$ \\
\hline Center of Interest & $\begin{array}{c}\text { Berdasarkan ceritanya, yang menjadi objek } \\
\text { utama dalam karya ini adalah objek manusia } \\
\text { dengan perahunya, namun ada beberapa } \\
\text { objek yang justru lebih menonjol sehingga } \\
\text { objek utamanya tertutupi. }\end{array}$ \\
\hline
\end{tabular}

Tabel 3.Rekapitulasi Seluruh Karya Kaca Patri

\begin{tabular}{|c|c|c|}
\hline No. & Kaca Patri & Skor \\
\hline 1 & Penciptaan & $\mathbf{3}$ \\
\hline 2 & Adam dan Hawa & $\mathbf{4}$ \\
\hline 3 & Sakramen Perkawinan & $\mathbf{5}$ \\
\hline 4 & Keluarga Kudus di Nazareth & $\mathbf{4}$ \\
\hline 5 & Bahtera Nuh & $\mathbf{1}$ \\
\hline \multicolumn{2}{|c|}{ Jumlah $\mathbf{1 7}$} \\
\hline
\end{tabular}

\section{SIMPULAN}

Berdasarkan prinsip seni, kualitas estetis pada hiasan-hiasan kaca patri ini masih memiliki kekurangan dapat dilihat dari tabel rekapitulasi penilaian yang terdapat karya dengan perolehan poin di bawah $3(<3)$ yang berarti prinsip seni tidak terwujud sepenuhnya didalam karya-karya tersebut, namun ada juga beberapa kaca yang sudah memiliki kualitas yang baik $(>3)$ menurut tinjauan prinsip seni. Beberapa kekurangan yang terlihat ialah pembentukan proporsi objek didalamnya serta pemilihan warna yang kurang tepat dalam beberapa hiasan kaca patri ini. Hal ini mungkin dikarenakan kurangnya referensi hingga kemampuan dalam pembentukannya yang masih kurang memadai, mengingat seni kaca patri adalah seni yang terbilang masih sangat jarang diterapkan di daerah tersebut. Dalam penerapannya, jenis karya kaca patri ini cenderung mengarah kepada aliran kubisme, terlihat upaya penggambaran objek-objek yang di bentuk dari bidang-bidang yang cukup lebar. Namun dalam beberapa karya juga mengandung unsur karya yang mengarah pada jenis simbolik.

\section{DAFTAR PUSTAKA}

Arikunto, S. (2006). Prosedur Penelitian Suatu Pendekatan Praktek. Jakarta: Rineka Cipta.

Fichner, L. (1992). Understanding Art. New Jersey: Prentice Hall.

Hudson, T. (2008). The History of Stained Glasa (The Art of Light Medievalto Contemporary). London: Virginia Chieffo Raguin.

Hutama, K. (2005). Seni Ragam Hias Stained Glass Pada Bangunan-Bangunan Di Jakarta, Jurnal Dimensi Seni Rupa.2(2): 99-101.

Moelya. (2014). Art Glass. Diunduh di http://moeltaartglass.blogspot.com tanggal 9 April 2021.

Nainggolan, M. (2018). Analisis Karya Gambar Bentuk Siswa Kelas VII SMP Negeri 1 Simangumban Berdasarkan Prinsip-Prinsip Seni Rupa, Skripsi. Universitas Negeri Medan.

Narbuko,C. (2005). Metode Penelitian. Jakarta: PT. Bumi Aksara.

Prema, S. (2015). Analisis Bentuk Relief Di Kuil Shri Mariamman Medan Ditinjau Dari Prinsip-Prinsip Seni Rupa, Skripsi. Universitas Negeri Medan.

Putri, D.M. (2012). Aplikasi Ornament Kaca Patri Pada Busana Casual Dengan Teknik Digital Print dan Bordir, Jurnal Tingkat Sarjana Senirupa dan Desain. 1(1): 7. 
Samuel Joan Parasian Siregar, Tinjauan Estetis Hiasan Kaca Patri Pada Gereja Katolik Inkulturatif Paroki Santo

Fransiskus Asisi, Berastagi Berdasarkan Prinsip Seni Rupa

Sinaga, D., \& Triyanto, R. (2020). Tinjauan Ilustrasi Cover Novel Harry Potter Edisi Indonesia Karya Nicolas Fiber Ditinjau Dari Elemen Visual. Journal of Education, Humaniora and Social Sciences (JEHSS), 3(1), 265-272. doi:https://doi.org/10.34007/jehss.v3i1.292

Sugiyono. (2010). Metode Penelitian Kuantitatif Kualitatif. Dan R\&D. Bandung: Alfabeta.

Utami, A., Soeprayogi, H., \& Azis, A. (2020). Pembuatan Kerajinan Bunga Berbahan Kulit Jagung Ditinjau dari Prinsip-prinsip Seni Rupa dan Kerajinan. Journal of Education, Humaniora and Social Sciences (JEHSS), 3(1), 260-264. doi:https://doi.org/10.34007/jehss.v3i1.282

Utoyo, J., Priyatno, A., \& Azis, A. (2020). Penerapan Prinsip-Prinsip Seni Rupa Pada Kaligrafi Di Masjid Baiturrahman Unimed. Journal of Education, Humaniora and Social Sciences (JEHSS), 3(2), 419-426. doi:https://doi.org/10.34007/jehss.v3i2.330

Warrington, W. (1998). The History of Stained Glass. London: Berkeley Street West. 